\title{
Konflik peran ganda dan stres kerja karyawati yang bekerja di Bank XXX Kanca Dharmasraya
}

\author{
Ria Okfrimaa,1*, Beli Natura ${ }^{b, 2}$, Herio Rizki Dewindac,3 \\ a,b,cFakultas Psikologi, Universitas Putra Indonesia YPTK, Padang \\ *1ria.okrima.chan@gmail.com; 2belly.natura16@gmail.com; 3hrdewinda@gmail.com \\ *Correspondent Author
}

Received: 11-03-2021

Revised: 14-06-2021

Accepted: 01-12-2021

\section{KATAKUNCI}

konflik;

konflik peran ganda;

stres kerja;
KEYWORDS

conflict;

dual role conflict;

work stress;

\section{ABSTRAK}

Bekerja sebagai karyawan Bank merupakan salah satu pekerjaan yang cukup banyak diminati masyarakat. Hal tersebut dikarenakan selain bergengsi, gaji yang didapatkan juga relatif besar dan berbanding lurus dengan tuntutan kerja yang diemban karyawan, yang kemudian berpotensi besar pula untuk mengalami stres dalam bekerja. Khususnya bagi karyawati, mengingat secara empirik salah satu hasil penelitian sebelumnya menjelaskan bahwa karyawan wanita yang bekerja di Bank memiliki tingkat stres yang lebih tinggi dibandingkan dengan karyawan pria. Oleh karena itu, untuk melakukan antisipasi tingginya tingkat stres yang dialami oleh karyawati yang bekerja di perbankan, maka penting untuk menguji hubungan antara konflik peran ganda dengan stres kerja karyawati yang bekerja di Bank, mengingat penelitian ini masih sangat jarang ditemui dalam konteks perbankan. Dengan demikian penelitian ini bertujuan untuk melihat hubungan antara konflik peran ganda dengan stres kerja karyawati yang bekerja di Bank XXX Kanca Dharmasraya. Pendekatan pada penelitian ini menggunakan pendekatan kuantitatif dengan metode korelasi. Teknik pengambilan sampel yang digunakan dalam penelitian ini adalah purposive sampling dengan jumlah sampel penelitian sebanyak 31 orang. Alat ukur yang digunakan dalam penelitian ini adalah skala konflik peran ganda dan skala stres kerja. Hasil analisis data menunjukkan besarnya koefisien korelasi sebesar $r=0,609$ dengan taraf signifikan $p=0,000(p<0,01)$, sehingga dapat disimpulkan bahwa ada hubungan yang sangat signifikan dengan arah positif antara konflik peran ganda dengan stres kerja karyawati yang bekerja di Bank XXX Kanca Dharmasraya.

\section{Dual role conflict and work stress of female employees working at Bank XXX Kanca Dharmasraya}

Working as a Bank employee is one of the immensely popular jobs with the public. It is because, besides being prestigious, the salary obtained is also relatively large; in this case, it is directly proportional to the work demands carried out by employees, which then has a great potential to suffer stress at work. Especially for female employees, considering that empirically one of the previous research results explained that female employees who work at the Bank have a higher stress level than male employees. Therefore, to anticipate the high level of stress experienced by employees who work in banking, it is crucial to examine the relationship between dual role conflict and work stress of employees who work in banks, considering that this research is still scarce in the 
context of banking. Thus, this study aims to examine the relationship between dual role conflict and the work stress of female employees at Bank XXX Kanca Dharmasraya. The approach in this study uses a quantitative approach with the correlation method. The sampling technique used in this study was purposive sampling with a total sample of 31 people. The measuring instrument used in this research is the multiple role conflict scale and the work stress scale. The data analysis results show the magnitude of the correlation coefficient of $r=0.609$ with a significant level of $p=0.000(p<0.01)$, so it can be concluded that there is a very significant relationship with a positive direction between dual role conflict and work stress of female employees working at Bank XXX Kanca Dharmasraya.

This is an open-access article under the CC-BY-SA license.

\section{Pendahuluan}

Pekerjaan merupakan salah satu sarana bagi individu untuk dapat memenuhi kebutuhan hidup. Dilansir dari salah satu media informasi (Muliana, 2016) bahwa salah satu jenis pekerjaan bergengsi adalah menjadi karyawan di perusahaan perbankan. Namun demikian, lebih lanjut disampaikan bahwa menjadi karyawan Bank merupakan salah satu jenis pekerjaan dengan tingkat stres paling tinggi nomer dua selain dokter. Hal tersebut dikarenakan pekerjaan yang dilakukan oleh seorang karyawan Bank tergolong sangat banyak, bahkan rata-rata karyawan dituntut untuk bekerja selama 120 jam seminggu demi menyelesaikan beberapa proyek.

Stres sendiri disampaikan oleh Beehr dan Newman (1978) sebagai suatu bentuk tanggapan atau respon secara fisik maupun mental seseorang terhadap lingkungannya yang dirasakan menganggu dan mengancam dirinya dan mempengaruhi proses berfikir, emosi dan kondisi fisik seseorang. Riggio (2017) menjelaskan stres kerja sebagai reaksi fisiologis dan atau psikologis terhadap suatu kejadian yang dipersepsi individu sebagai ancaman. Stres kerja merupakan sebuah respon adaptif, dihubungkan oleh karakteristik dan proses psikologi individu yang merupakan suatu konsekuensi dari setiap tindakan eksternal, situasi atau peristiwa yang menempatkan tuntutan psikologis dan atau fisik khusus pada seseorang (Ivancevich, Matteson, Freedman, \& Phillips, 1990). Stres yang terjadi di tempat kerja merupakan hasil reaksi emosi dan fisik akibat kegagalan individu beradaptasi di lingkungan kerja dimana terjadi ketidak sesuaian antara harapan dan kenyataan.

Dampak dari stres kerja tidak hanya berpengaruh bagi individu namun juga bagi perusahaan tempat individu tersebut bekerja. Artinya, dampak dari stres kerja dapat menimbulkan kerugian baik bagi individual karyawan maupun bagi perusahaan, sehingga perlu dilakukan sebuah tindakan guna meminimalisir tingkat stres kerja. Selanjutnya, Keenan dan Newton (1987) berpendapat bahwa stres kerja adalah perwujudan dari kekaburan peran, konflik peran dan beban kerja yang berlebihan, sehingga kondisi tersebut dapat mengganggu prestasi dan kemampuan individu untuk bekerja. Sesuai dengan yang disampaikan sebelumnya, Cooper, Russell, \& Frone (1990) mengidentifikasikan salah satu faktor yang mempengaruhi stres kerja adalah peran, dalam hal ini khususnya karena konflik peran yang dimiliki.

Seperti yang disampaikan Keenan dan Newton (1987), Cooper, et al. (1990), hasil penelitian Firdaus (2014) turut menjelaskan bahwa karyawan Bank dengan jenis kelamin wanita memiliki tingkat stres kerja lebih tinggi dibandingkan dengan karyawan pria. Hal 
tersebut selaras dengan yang disampaikan Rice (1999) bahwa wanita mengalami stres kerja lebih tinggi dibanding laki-laki. Stres yang biasa wanita alami dapat disebabkan oleh banyaknya tekanan baik tekanan di tempatnya bekerja maupun tekanan karena tuntutan di rumah. Wanita yang bekerja kebanyakan mengalami konflik dan permasalahan serta lebih menekankan pentingnya permasalahan keluarga dibandingkan pekerjaan ketika keluarga sebagai domain yang paling penting dari kebanyakan wanita (Cinnamon \& Rich, 2002). Dampak yang paling banyak pada ibu yang bekerja sekaligus ibu rumah tangga adalah stres yang terjadi akibat kedua peran tersebut. Stres kerja yang dihadapi ibu yang memiliki peran ganda kebanyakan berasal dari keluarga dan tempat kerja yang mempunyai beban kerja lebih banyak.

Berbicara tentang konflik peran ganda, Katz dan Kahn (1978) menjelaskan konflik peran ganda sebagai bentuk dari konflik antar peran yang mana disebabkan oleh adanya tekanan peran dari pekerjaan dan keluarga secara bertentangan. Paden dan Buchler (1995) mendefinisikan konflik peran ganda sebagai konflik peran yang muncul antara harapan dari dua peran yang berbeda yang dimiliki oleh seseorang. Menurut Ivancevich, et al. (1990) konflik peran ganda muncul ketika seseorang menerima pesan yang tidak sebanding berkenaan dengan perilaku peran yang sesuai. Frone, Russell dan Cooper (1997) mengungkapkan konflik peran ganda merupakan konflik peran yang terjadi pada karyawan, dimana di satu sisi harus melakukan pekerjaan di kantor dan di sisi lain harus memperhatikan keluarga secara utuh, sehingga sulit membedakan antara pekerjaan mengganggu keluarga dan keluarga mengganggu pekerjaan.

Konflik keluarga-pekerjaan dapat mengarah pada stres kerja dikarenakan banyaknya waktu yang dibutuhkan dalam menangani urusan pekerjaan dan hal tersebut merupakan sumber potensi untuk terjadinya stres kerja (Judge \& Colquitt, 2004). Tekanan untuk mengembangkan dua peran tersebut dapat menyebabkan timbulnya stres. Konflik pekerjaankeluarga merupakan salah satu bentuk konflik antar peran dimana tekanan dari pekerjaan mengganggu pelaksanaan peran keluarga. Thomas dan Ganster (1995) menyatakan bahwa $38 \%$ pria dan $43 \%$ wanita yang sudah menikah serta memiliki pekerjaan dan anak, dilaporkan mengalami konflik pekerjaan-keluarga dan keluarga-pekerjaan terhadap stres kerja dan hasil yang diperoleh mengindikasikan bahwa tekanan untuk menyeimbangkan stres kerja tetapi juga ketidakpuasan kerja, depresi, kemangkiran dan bahkan penyakit.

Penelitian tentang stres kerja yang dikaitkan dengan konflik peran ganda pada dasarnya sudah cukup banyak dilakukan oleh peneliti sebelumnya. Namun demikian, penelitian yang mengkaitkan dengan populasi pada pegawai Bank sendiri masih sangat jarang ditemui. Oleh karena itu, berdasarkan fenomena dan kajian teoritis yang telah dipaparkan sebelumnya, maka tujuan penelitian ini adalah untuk mengetahui hubungan antara konflik peran ganda dengan stres kerja pada karyawan wanita yang telah menikah di Bank XXX Kanca Dharmasraya. Hasil penelitian ini diharapkan dapat menjadi masukan bagi disiplin ilmu Psikologi Industri dan Organisasi, khususnya mengenai pengetahuan tentang pengelolaan sumber daya manusia, terutama mengenai hubungan antara konflik peran ganda dengan stres kerja pada wanita bekerja.

\section{Metode}

Pendekatan yang digunakan pada penelitian ini adalah pendekatan kuantitatif dengan metode korelasi. Populasi pada penelitian ini adalah seluruh karyawati yang telah menikah dan bekerja di Bank XXX Kanca Dharmasraya. Adapun teknik pengambilan sampel dalam penelitian ini menggunakan teknik purposive sampling, yaitu sampel bertujuan dilakukan dengan cara mengambil subjek bukan didasarkan atas strata, random atau daerah tetapi didasarkan atas adanya tujuan tertentu dengan pertimbangan peneliti sehingga dapat mewakili populasi (Arikunto, 2014). Pertimbangan yang dilakukan peneliti untuk 
menentukan sampel bahwa sampel memenuhi karakteristik karyawan wanita yang telah menikah dan mempunyai anak. Jumlah sampel yang memenuhi karakteristik populasi pada penelitian ini adalah sebanyak 31 orang. Metode pengumpulan data pada penelitian ini menggunakan dua skala yaitu skala konflik peran ganda dan stres kerja. Adapun koefisien reliabilitas dari skala konflik peran ganda adalah sebesar $r_{x x^{\prime}}=0,943$. Sementara koefisien reliabilitas dari skala stres kerja adalah sebesar $r_{x x^{\prime}}=0,942$. Selanjutnya, data yang telah dikumpulkan diolah dengan menggunakan teknik korelasi product moment dari Pearson.

\section{Hasil}

Berdasarkan hasil uji korelasi Product Moment (Pearson) yang dilakukan dengan bantuan IBM SPSS 21.0, dimana level of significant $(\alpha)$ 0,01, dan diperoleh nilai (p) sig 0,000 serta koefisien korelasi $(r)=0,609, \mathrm{p}<0,01$ maka hipotesis diterima. Hal ini menunjukkan bahwa terdapat hubungan yang sangat signifikan antara konflik peran ganda dengan stres kerja pada karyawati yang bekerja di Bank XXX Kanca Dharmasraya. Selanjutnya sumbangan efektif $\left(R^{2}\right)$ dari variabel konflik peran ganda terhadap stres kerja adalah sebesar $R^{2}=0,371$ $(37,1 \%)$.

\section{Pembahasan}

Hasil penelitian ini menunjukan adanya hubungan yang sangat signifikan antara konflik peran ganda dengan stres kerja pada karyawan wanita yang telah menikah di Bank XXX Kanca Dharmasraya. Adanya hubungan positif tersebut dapat diartikan bahwa semakin tinggi konflik peran ganda, maka semakin tinggi stres kerja. Begitu juga sebaliknya, semakin rendah konflik peran ganda, maka semakin rendah stres kerja. Temuan pada penelitian ini sesuai dengan hasil penelitian yang dilakukan oleh Benyamin (2013) pada karyawati di CV Semoga Jaya Samarinda yang mengungkapkan adanya hubungan yang signifikan antara konflik peran ganda dengan stres kerja. Selanjutnya penelitian dari Wulandari dan Wibowo (2013) menelaskan adanya hubungan yang signifikan antara konflik peran ganda dengan stres kerja perawat wanita yang sudah menikah di RSUD Banyumas. Pada penelitian tersebut dijelaskan bahwa semakin tinggi konflik peran ganda maka semakin tinggi pula stres kerja yang dialami oleh perawat. Begitu pula sebaliknya, semakin rendah konflik peran ganda yang dialami perawat maka semakin rendah pula stres kerja yang dialami oleh perawat yang bekerja di RSUD Banyumas.

Amalia (2005) mengemukakan bahwa wanita yang menjalankan peran ganda, sebagai karyawan sekaligus ibu rumah tangga lebih sering dihinggapi stres daripada pekerja wanita yang lajang. Banyak wanita yang menjalankan peran ganda tidak mampu mengatasi stres yang dialami terutama tuntutan untuk berprestasi dari perusahaan tempat individu bekerja atau untuk mendapatkan penghasilan yang lebih banyak. Selanjutnya wanita yang bekerja terkadang dianggap kurang memperhatikan keluarganya, karena memiliki dua peran sekaligus yang masing-masing memiliki tuntutan yang sama pentingnya. Dengan demikian hal ini akan menimbulkan stres pada wanita jika tidak dapat menjalakan kedua perannya dengan baik, karena tekanan-tekanan yang di terima.

Konflik peran individu terjadi ketika pengharapan dalam hal kinerja salah satu peran menimbulkan kesulitan dalam peran lain. Konflik pekerjaan-keluarga cenderung mengarah pada stres kerja karena ketika urusan pekerjaan mencampuri kehidupan keluarga, tekanan sering kali terjadi pada individu untuk mengurangi waktu yang dihabiskan dalam pekerjaan dan menyediakan lebih banyak waktu untuk keluarga. Hal tersebut sesuai dengan yang disampaikan Habibi dan Jefri (2018) bahwa konflik peran merupakan salah satu faktor yang memepengaruhi stres kerja. Sama halnya dengan konflik keluarga-pekerjaan dapat mengarah pada stres kerja dikarenakan banyaknya waktu yang dibutuhkan dalam menangani urusan pekerjaan dan ini merupakan sumber potensian terjdinya stres kerja (Judge, et al., 2004). 
Melalui hasil pengolahan data penelitian didapatkan bahwa 13\% dari seluruh sampel penelitian mengalami konflik peran ganda yang rendah, 71\% mengalami konflik peran ganda yang sedang dan 16\% yang mengalami konflik peran ganda yang tingi. Sementara itu, dapat digambarkan bahwa 7\% dari seluruh sampel penelitian mengalami stres kerja yang rendah, $77 \%$ mengalami stres kerja yang sedang dan 16\% mengalami stres kerja yang tinggi. Besarnya sumbangan efektif konflik peran ganda dengan stres kerja adalah sebesar $37,1 \%$. Hal ini dapat diartikan bahwa konflik peran ganda dengan stres kerja berkontribusi secara positif sebesar $37,1 \%$ sedangkan sebanyak $62,9 \%$ sisanya dipengaruhi oleh faktor-faktor lain. Secara teoritis dan empirik berdasarkan hasil penelitian sebelumnya menjelaskan bahwa variabel lain yang dapat mempengaruhi stres kerja, diantaranya seperti harga diri (Dipboye, Smith, \& Howell,1994; Gibson \& Donnelly, 1994), jenis kelamin, jadwal kerja, konflik interpersonal (Habibi \& Jefri, 2018), locus of control, kondisi fisik, tipe kepribadian, dan gaya hidup (Dipboye, et al, 1994).

\section{Simpulan}

Berdasarkan hasil analisis penelitian yang telah dilakukan maka dapat ditarik kesimpulan bahwa terdapat hubungan yang sangat signifikan antara konflik peran ganda dengan stres kerja karyawati yang bekerja di Bank XXX Kanca Dharmasraya. Hasil penelitian ini mengungkapkan bahwa semakin tinggi konflik peran ganda maka semakin tinggi stres kerja. Begitu juga sebaliknya, semakin rendah konflik peran ganda, maka semakin rendah stres kerja. Besarnya sumbangan efektif variabel konflik peran ganda dengan stres kerja adalah sebesar $37,1 \%$. Berdasarkan penelitian yang telah dilakukan tentang konflik peran ganda dengan stres kerja pada karyawati yang bekerja di Bank XXX Kanca Dharmasraya maka bagi peneliti selanjutnya yang tertarik dan berminat dengan permasalahan konflik peran ganda dengan stres kerja ini disarankan untuk dapat mengkaji dari sisi populasi penelitian yang berbeda, seperti konflik peran ganda dengan stres kerja yang dialami oleh single father.

\section{DAFTAR PUSTAKA}

Amalia, M. (2005). Konflik peran ganda ibu bekerja ditinjau dari dukungan sosial. Skripsi. Semarang: Fakultas Psikologi Universitas Katolik Soegijapratana.

Arikunto, S. (2014). Prosedur penelitian suatu pendekatan praktik. Jakarta: Rineka Cipta.

Beehr, T. A. \& Newman, J. E. (1978). Job stress, employee healt and organization effectiveness: A facet analisis model, and literature review. Personnel Psychology. 31.665-669. https://doi.org/10.1111/j.1744-6570.1978.tb02118.x.

Benyamin. (2013). Hubungan antara konflik peran ganda dengan stres kerja pada karyawati di CV. Semoga Jaya Samarinda. Indonesian Publication Index. Vol.1 No.1 Page.49.

Cinamon, R. G., \& Rich, Y. (2002). Gender differences in the importance of work and family roles: Implications for work-family conflict. Sex roles, 47(11), 531-541. https://doi.org/10.1023/A:1022021804846.

Cooper, M. L., Russell, M., \& Frone, M. R. (1990). Work stress and alcohol effects: A test of stress-induced drinking.Journal of health and social behavior, 260-276. https://doi.org/10.2307/2136891.

Dipboye, R. L., Smith, C. S., \& Howell, W. C. (1994). Understanding an industrial integrated organizational approach psychology. Florida: Hacourt Brace.

Firdaus, R. A. (2014). Perbedaan stres kerja dan kepuasan kerja antara karyawan laki-laki dan perempuan di PT. Bank Rakyat Indonesia (Persero), Tbk. Kantor Cabang Martadinata Malang. Skripsi. Malang: Universitas Negeri Malang. 
Frone, M. R., Russell, M., \& Cooper, M. L. (1997). Relation of work-family conflict to health outcomes: A four-year longitudinal study of employed parents. Journal of Occupational and Organizational psychology,70(4), 325-335. https://doi.org/10.1111/j.20448325.1997.tb00652.x.

Gibson, J. L. J. M., \& Donnelly Jr, J. H. (1994). Organizations: behavior, structure, processes/James L. Gibson, John M. Ivancevich, James H. Donnelly, Jr (No. 658.4 G5 1994).

Habibi, J., \& Jefri. (2018). Analisis faktor risiko stres kerja pada pekerja di unit produksi PT. Borneo Melintang Buana Export. Journal of Nursing and Public Health, 6(2), 50-59. https://doi.org/10.37676/jnph.v6i2.658.

Ivancevich, J. M., Matteson, M. T., Freedman, S. M., \& Phillips, J. S. (1990). Worksite stress management interventions. American Psychologist, 45(2), 252261. https://doi.org/10.1037/0003-066X.45.2.252.

Judge, T. A., \& Colquitt, J. A. (2004). organizational justice and stress: The mediating role of work-family conflict. Journal of Applied Psychology, 89(3), 395404. https://doi.org/10.1037/0021-9010.89.3.395.

Katz, D., \& Kahn, R. L. (1978). The social psychology of organization (2nd. ed.). New York: John Willey and Sons.

Keenan, A., \& Newton, T. J. (1987). Work difficulties and stress in young professional engineers. Journal of Occupational psychology,60(2), 133-145. https://doi.org/10.1111/j.2044-8325.1987.tb00246.x

Muliana, V. A (2016). 5 Pekerjaan bergaji besar dengan tingkat stres tinggi. https://www.liputan6.com/bisnis/read/2491946/5-pekerjaan-bergaji-besar-dengantingkat-stres-tinggi.

Paden, S. L., \& Buehler, C. (1995). Coping with the dual-income lifestyle. Journal of Marriage and the Family, 101-110. https://doi.org/10.2307/353819.

Rice, P. L. (1999). Stress and health. Pacific Grove, CA: Brooks/Cole Publishing.

Riggio, R. E. (2017). Introduction to industrial/organizational psychology. Routledge. https://doi.org/10.4324/9781315620589.

Thomas, L. T., \& Ganster, D. C. (1995). Impact of family-supportive work variables on workfamily conflict and strain: A control perspective. Journal of Applied Psychology, 80(1), 615. https://doi.org/10.1037/0021-9010.80.1.6.

Wulandari, D., \& Wibowo, U. D. A. (2013). Hubungan antara konflik peran ganda dengan stres kerja pada perawat wanita yang sudah menikah di RSUD Banyumas. Psycho Idea, 11(1), 69-78. https://doi.org/10.30595/psychoidea.v11i1.258. 